\title{
Sustainability is possible: The national institution - university library (NIUL) in Macedonia as a leader of societal development
}

\section{Lili Boshevska}

lilibitola@gmail.com Bitola, Macedonia.

\begin{abstract}
$^{1}$
The challenge for the national libraries in Macedonia is to fulfill the national library policies, as set by The Law for Libraries and The Law for Culture. The National interest in culture is a public interest for all the citizens of the Republic of Macedonia and its most important aspect is the availability of culture to all of the citizens under the same conditions: -Ensuring suitable conditions for preserving the cultural heritage; -Encouraging diversity in culture;-Enabling access to cultural values and their sharing;-Creating conditions for preserving the cultural identities of the different communities;-Ensuring equal and even cultural development in Macedonia;-Affirmation of Macedonia's culture and cultural diversity abroad.The circumstances and conditions created by the law make a foundation for upgrading the contribution of the National Libraries towards development of the United Nations' Sustainable Development Goals.National Institution - University Library (NIUL) in Bitola is faced with the challenge to create its own library policies comparing and using the existing frameworks or models for library and information policies from across the world, and contribute towards development with emphasis on the social dimension of sustainable development. The focus of this paper is to answer to the question: What is the Library's role as a National Institution in calling for action and helping the process of positive changes to our world.The paper will explain the connectivity of the National Institution- University Library (NIUL) "Sv. Kliment Ohridski" Bitola, with the five areas of critical importance for humanity and the planet: People, Planet, Prosperity, Peace, and Partnership. It describes the possibilities of opening debates and taking action to accomplish the goals and targets of the United Nations' Document: "Transforming our world: the 2030 Agenda for Sustainable Development".
\end{abstract}

KEYWORDS: National libraries. Library roles. Sustainable development goals. Macedonia.

\footnotetext{
${ }^{1}$ This paper was previously presented and published in the proceedings of the IFLA World Library and Information Congress 2016.
} 


\section{INTRODUCTION}

The national libraries in Macedonia, as public non-profit institutions in the field of culture, plan and organize their activities in accordance with the national strategy for cultural development. The national strategy is passed by the Parliament in 5 year periods in order to fulfill the national interests in culture. It is passed as a strategic document that defines mid-term goals and priorities for cultural development and determines the organizational, financial, and administrative measures to accomplish these goals. Various stake holders participate in defining the national strategy, namely, high-educational and scientific institutions, civic societies for culture and representatives of the independent cultural scene. The national strategy draft is put on a public forum and debate before it is brought to the Parliament. The national strategy is governed by the Law for culture, with which the national interests in culture are defined. (Article 9 of the Law for Culture, "Gazette of the Republic of Macedonia" 31/98, 49/03, 82/05, 24/07, 116/10, 47/11, 51/11, 136/12, 23/13, 187/13, 44/14, $61 / 15$ and 154/15 Constitutional Court ruling 196/2007 from 16.01.2008 published in the "Gazette of the Republic of Macedonia" 15/2008).

The national strategy for cultural development from 2013-2017 has the following goals and priorities:

- To encourage the development of the cultures, in its full complexity of the

- Heritage traditional and ethno-cultural identity of the Macedonian people and community, and other communities living in Macedonia

- Multicultural reality of the Macedonian society

- Aesthetic pluralism of the artistic values

- Humanistic, ethical, educational, entertainment, economic, manufacturing, cohesive and other dimensions of culture

- To align the developmental politics in Macedonia with the relevant politics of international character (United Nations, United Nations Educational Scientific and Cultural Organization, Council of Europe, European Union)

- To foster the communication of the separate cultural identities, raising awareness of culture as a field of societal and national interest

- To establish a positive financial and material ambient for a long-term cultural development by increasing the budgetary spending for financing cultural activities

- To stimulate the creative artistic potential of their ethnic, religious, ideological, political, social views or beliefs, gender or age.

- To enable young talents getting proper education, educate the citizens in the field of culture and arts, and to apply new methods for cultural education in the educational system.

- To establish and maintain a cooperation between culture and other sectors, namely, education and science, international politics and tourism, as well as other sectors which are implemented in culture 
- To encourage the founding of research institutions in the field of culture (e.g. Institute for culture, Book Center, Scientific center for research in cultural heritage)

- To develop a special fund in order to lease web-space in order to affirm the culture of Macedonia internationally, and improve the information on Macedonia's cultural history.

- To support the publication of a referent magazine for culture and arts, as well as publishing publications relevant for particular cultural activities (with an international character)

- To support projects promoting Macedonian culture internationally

- To protect cultural heritage regardless of its historical, civilizational or ethno-cultural distinctions

- To digitalize modern art as part of the contemporary cultural wealth of Macedonia

- To ensure there are conditions for increasing the number of cultural sites under the protection of UNESCO

- To improve the intellectual property protection in culture and arts.

The circumstances and conditions created by the law make a foundation for upgrading the contribution of the National Libraries towards development of the United Nations' Sustainable Development Goals.

\section{WHAT WAS DONE AND WHAT SHOULD BE DONE FOR SUSTAINABLE DEVELOPMENT}

In accordance with the Millennium Development Goals (MDGs) from 2000, the Republic of Macedonia pledged to improve policies and governance and increase accountability to Macedonian citizens. To achieve these goals, the Government of the Republic of Macedonia implemented new legal solutions for different Ministries and upgraded the existing National Policies and Strategies for instance the National Strategy for Cultural Development, National Strategy to reduce Poverty and Social Exclusion in Republic of Macedonia (NSPSERM), National Youth Strategy, National Strategy for Informatics' Society and Administration, National Education Policies. All these documents are built on the Millennium Development Goals, which are transformed and upgraded in the Sustainable Development Goals (SDGs), agreed to by 193 world leaders in 2015.

The SDGs are a 17-point plan to end poverty, combat climate change and fight injustice and inequality:

SDG 1: End poverty in all its forms everywhere

SDG 2: End hunger, achieve food security and improve nutrition and promote sustainable agriculture

SDG 3: Ensure healthy lives and promote wellbeing for all at all ages

SDG 4: Ensure inclusive and quality education for all and promote lifelong learning

SDG 5: Achieve gender equality and empower all women and girls 
SDG 6: Ensure access to water and sanitation for all

SDG 7: Ensure access to affordable, reliable, sustainable and modern energy for all

SDG 8: Promote inclusive and sustainable economic growth, employment and decent work for all

SDG 9: Build resilient infrastructure, promote sustainable industrialization and foster innovation

SDG 10: Reduce inequality within and among countries

SDG 11: Make cities inclusive, safe, resilient and sustainable

SDG 12: Ensure sustainable consumption and production patterns

SDG 13: Take urgent action to combat climate change and its impacts

SDG 14: Conserve and sustainably use the oceans, seas and marine resources

SDG 15: Sustainably manage forests, combat desertification, halt and reverse land degradation, halt biodiversity loss

SDG 16: Promote just, peaceful and inclusive societies

SDG 17: Revitalize the global partnership for sustainable development

The SDGs can be considered as a to-do-list for humanity and the planet which can be achieved if everyone plays their part. The libraries can play their part as well. All national and international documents, where the SDGs are integrated, can be the frames where libraries can find the possibility for partnership with other institutions and to build their own commitment to the SDGs. The National Libraries, in particular, can become relevant strategic partners in achieving the aims and goals. Every library has a responsibility to take on an active role in society and become an active partner in societal development, whether it is economic, environmental or social. This implies that the SDGs are a new challenge not just for the Government of Macedonia and the Ministry for Culture but also for the libraries themselves.

The NIUL in Bitola takes on the challenge of answering how this library will contribute towards accomplishing the SDGs in the five areas of critical importance for humanity and the planet: People, Planet, Prosperity, Peace, and Partnership.

People: How can the Library contribute "to end poverty and hunger, in all their forms and dimensions, and to ensure that all human beings can fulfill their potential in dignity and equality and in a healthy environment"? (UNITED NATIONS, 2015). The library can be treated as a resource center that is rich with information that must be made available to people of every age, social and ethnic background. The library is not just a treasury for books, but it should be put in the people's service as an architect of personal, intellectual, and community growth.

Planet: The library can develop its own system of projects and ecological actions that can help to promote and implement the ideas and actions "to protect the planet from degradation, including through sustainable consumption and production, sustainably managing its natural resources and taking urgent action on climate change". With collaboration with the NGOs, educational institutions and Local Communities, the library will connect all interested parties, 
"so that it can support the needs of the present and future generations" (UNITED NATIONS, 2015). The development of standards for an Eco Library is the top priority where the NIUL can contribute. The five ecological standards the library strives to implement are: 1.Saving energy 2.Saving water 3.Maintenance of the library building and maintaining a healthy environment in the library using ecological methods 4.Maintaining an environmentally friendly yard 5.Waste Management

Prosperity: One of the biggest challenges the NIUL is facing is how to "ensure that all human beings can enjoy prosperous and fulfilling lives and that economic, social and technological progress occurs in harmony with nature." (UNITED NATIONS,2015). The library can show the way to prosperity, by sharing the positive practices from all over the world and connecting the experts from different areas to make alignment with technological, economic, legal, ecological and social development.

Peace: The library is a potential place where people can share initiatives, ideas for justice, inclusiveness, peace, nonviolence; a place where the community can fight fear, prejudice and stereotypes. "There can be no sustainable development without peace and no peace without sustainable development."(UNITED NATIONS, 2015).

Partnership: The Library should be determined to make different kinds of partnerships in order to acquire the means required to implement the SDGs. The Library can focus on the needs of the different marginalized groups which are the poorest and most vulnerable people. Through Partnership the Library can make Connections with different countries and stakeholders in order to establish Cooperation with the relevant people ready to participate in improving the Community.

Having in mind the National Strategy for Cultural Development and all available National Strategies as a pronouncement of the government's perception and commitment to fulfill the SIGs in a particular sector, the NIUL Bitola will take many actions in order to achieve those goals. Because of the amount and complexity of the goals this paper covers only five of them $(1,3,4,5$ and 9) by selecting the targets connected with the different vulnerable groups in combating the poverty which is the priority for Macedonian society and for our Library as well. They are not just theoretical statements of intent but they are achievable in practice.

\section{Sustainable Development Goal 1: End poverty in all its forms everywhere}

\section{Practical situation and implication on society}

The international experience gained from the participatory evaluation of MDGs conducted in 12 countries of different development rates by the ATD Fourth World- an international organization that is working for overcoming poverty, can give an insight in how the libraries should approach the SDGs:"The inclusion of some developed countries emphasizes the fact that chronic poverty exists around the world, not only in those countries targeted by the MDGs." (ATD FOURTH WORLD, 2014) This conclusion shows that every country not matter how developed it is, should take on the challenge to fight poverty.

According to the NSPSERM 2010-2020, the poverty in Macedonia is present 
mostly in the socially vulnerable and marginalized groups, and it is more common in the Roma population, minorities, unemployed persons, persons with disabilities, elderly people, children at risk, people with chronic and malignant diseases, women, single parents. The findings of the national strategy will serve as a basis for measures and activities for social inclusion, which are assessed by the European Union. By strengthening the capacities that serve in building the national interests, all of the national institutions, including libraries, need to be considered in a framework for forming a strategic vision and policy. They also need to share the required knowledge in the domain of social concerns in order to achieve the task at hand. By increasing citizen rights, in accordance with the principles of the European Union (fundamental human rights, proportionality, legal certainty, equality before the law and subsidiarity), as with applying the strategy "EU 2020", Macedonia is aligning its social politics to those of the European union. By eliminating the stereotypes and by accepting the numerous innovations and solutions in this domain, the process of social inclusion is facilitated. Furthermore, it enables the overcoming of negative perceptions of people in different categories, vulnerable groups, and stigmatized individuals and communities.

"People living in poverty need time to build a collective understanding of their situation as well as to construct a sense of pride that counteracts their stigmatization and isolation. For better-off people, sharing power is frequently the most daunting challenge. It requires a commitment to a dialogue among equals, rooted in a sense of justice and a desire to develop more effective policies" (ATD FOURTH WORLD,2014) This can tell the Library how to take part in creating a national debate about fighting extreme poverty, violations of dignity and of all human rights worsened by processes of stigmatization, discrimination and humiliation.

\section{Library action- The role of the NIUL "Sv Kliment Ohridski" Bitola in developing}

\section{Goal 1}

What roles the NIUL Bitola can take:

-take activities for ensuring a greater social and cultural inclusion of the Roma community

-to start a debate for social inclusion, about fighting extreme poverty, violations of dignity and of all human rights worsened by processes of stigmatization, discrimination and humiliation.

-organizing public events called "Living library". In this unique Living Library, the "books" are actual persons who are stigmatized or marginalized because of their social, economic or cultural origin, status, gender, age, belief, appearance or life style. "Reading" these "books" is possible through constructive dialogue, as the best way in overcoming stereotypes and prejudices for others who are different, through authentic life stories

-providing free membership and other services in the Library for the different kinds of vulnerable groups 


\section{Practical situation and implications on society}

The World Health Organization defines health as: a state of complete physical, mental and social wellbeing, and not merely the absence of disease or infirmity. In line with this definition, reproductive health, means that people are able to have a responsible, satisfying and safe sex life; that they have the capability to reproduce and the freedom to decide if, when and how often to have children.

Reproductive health is underpinned by reproductive rights. These include, among others, the right to:

Decide the number, timing and spacing of children

Voluntarily marry and establish a family

The highest attainable standard of health

Be informed about and have access to safe, effective, affordable and acceptable methods of contraception

Have access to appropriate health care services during pregnancy and childbirth.

Reproductive health covers a wide range of topics, including:

Adolescent sexual and reproductive health

Cancers related to sexual and reproductive health

Family planning

Female genital mutilation

Infertility

Linkages between sexual and reproductive health and HIV

Maternal and newborn health

Sexually transmitted and reproductive tract infections

Stillbirths

Unsafe abortion

Violence against women

When women lack access to safe, comprehensive reproductive health care, the consequences can undermine not only their general health and wellbeing but also their social, economic and human development, and that of their families. The healthy life and wellbeing is also connected with taking care for the healthy food and water as relevant factor for having good health

The Library Action- The role of the NIUL "Sv. Kliment Ohridski" Bitola in
developing the Goal 3
The Library in Bitola can:
-Promote improved nutrition among school children and students
-Promote the books about human health and wellbeing in cooperation with
medical experts
-Deliver campaigns, debates, projects for combating the abuse and violence
against women and children
-Ensure universal access to information about sexual and reproductive health-
care services, including for family planning, information and education for well-
being for all at all ages.
In this case, The NIUL Bitola can establish and maintain cooperation with in


cooperation with the Medical Institutions: Secondary Education Medical School, High Medical School, Medical Care Centre and Clinical Centre-Hospital in Bitola.

Sustainable Development Goal 4: Ensure inclusive and equitable quality education and promote lifelong learning opportunities for all

The library is closely connected with education. The following library activities can be undertaken:

-Improving of early childhood development and overcoming adverse situations and phenomena in children at risk of poverty

-Helping children from socially vulnerable families in the process of learning, literacy and reading. Provide each child starts primary education to be ready and able to learn and to reap the full benefits of years spent in education

-Helping the schools in the process for motivating the children to read and write. -Cooperating with social workers, pedagogues and psychologists in primary and secondary schools, in order to ensure that the local community and local schools have close cooperation in terms of involving students in creative activities and encouraging philanthropic activities

-Providing a cultural preoccupation of the elderly with low incomes, participation in cultural events and providing them with free membership to the library

Sustainable Development Goal 5. Achieve gender equality and empower all women and girls

In accordance with the principles of the European Union and the national needs in the field of social inclusion, the "National Strategy to Reduce Poverty and Social Exclusion" also considers the gender dimension in all levels and fields, as one of the starting points of social inclusion. The recommendations include a gender-sensitive approach for facing social challenges.

In those lines the library can:

-enable women from vulnerable groups to get information for the access to skilled care in pregnancy and childbirth, and to learn how to care for their babies and older children, making possible to make rapid, significant progress in reducing the child mortality and improving the health of mothers and children through a program of participatory women's groups.

-involve women in leadership at all levels of decision-making in political, economic and public life

-make a connection between well educated and financially independent women with the women in social risk, and make the Library a bridge for empowering all women and girls, to get the best education, training and financial security.

Sustainable Development Goal 9. Build resilient infrastructure, promote inclusive and sustainable industrialization and foster innovation

The National Library can become a center for fostering innovation and the innovation culture. With emphasis on development of science, technology, engineering, and mathematics, the Library can build resilient infrastructure by creating maker spaces where the partners (formal and informal educational institutions: primary and secondary schools, technical faculty, NGOs, ICT 
businesses) will develop programs that embody the maker values of collaboration, risk-taking, creativity, and personalized learning. With focus on 21st century innovation skill building, the maker spaces are part of a growing movement of hands-on, mentor-led learning environments to make and remake the physical and digital worlds. Based on project-based learning and participatory learning, they foster experimentation, invention, creation, collaboration and exploration through design thinking, critical thinking and problem solving.

The NIUL can design and launch a public maker space lab to introduce adults and teens to the technologies enabling new forms of manufacturing, art and design, which can become a model of participatory learning space with activities in robotics; video and music production; applications, software and web-based tools; 3D modeling and printing; graphic design and writing.

\section{CONCLUSION - THE FINAL THOUGHTS}

Because the National Libraries in Macedonia are in the governance of The Ministry of Culture, the strategic direction is given by the National Policies and other documents for Culture (NATIONAL STRATEGY for Cultural Development 2004-2008; 2013-2017, Action Plans for Culture).

The majority of the Sustainable Development Goals were already covered in the actual documents, national library policies, national strategies and action plans, but there is a lot to be done until 2030.

The Library Policies as plans for action are more flexible than the National Policies, so the SIGs can be implemented in the library policies more readily. That is why the librarians in NIUL are eager to take on the challenge to develop the NIULs library policy with the intention to guide, influence and determine decisions and actions towards the SIGs.

NIUL "Sv. Kliment Ohridski" in Bitola is one of the five National Libraries in Macedonia and it has the functions of university, public and other types of libraries. The Ministry of Culture provides the financial and material resources for the program activities. The challenge for the Library is to provide a partnership with the community in order to provide additional financial and human resources needed for the additional project activities in order to accomplish SDGs. Every society has different needs and development levels. The question is how the library can find the weaknesses of that system and how it can improve that actual system. The most important part in that process is connecting with all relevant institutions, gaining cooperation among all relevant people in that institutions in order to create a support and development of the community. In deciding upon which goals and targets can be achieved by the NIUL in Bitola, this paper is taking into account the specific national reality, institutional capacity, level of development and respecting national policies and priorities. For the Library it is important to recognize the link between sustainable development and societal development. It is essential to establish a link among all relevant ongoing processes in the economic, social and environmental fields. 


\title{
Sustentabilidade é possível: A Biblioteca Nacional - Universidade Institucional (NIUL) na Macedonia como um líder de desenvolvimento social
}

\author{
RESUMO
}

O desafio para as bibliotecas nacionais na Macedônia é cumprir as políticas nacionais de bibliotecas, como fixado pela lei para bibliotecas e A Lei da Cultura. O interesse nacional na cultura é um interesse público para todos os cidadãos da República da Macedónia e seu aspecto mais importante é a disponibilidade de cultura para todos os cidadãos nas mesmas condições: - assegurar condições adequadas para a preservação do património cultural; -de Incentivar diversidade em cultura; -Acesso aos valores culturais e a sua partilha condições; -Criar para preservar as identidades culturais das diferentes comunidades; -Assegurar desenvolvimento igual e até mesmo cultural na Macedônia; Afirmation da cultura e da diversidade cultural da Macedónia no estrangeiro. As circunstâncias e condições criadas pela lei fazem uma fundação para atualizar a contribuição das Bibliotecas Nacionais para o desenvolvimento de Objetivos de Desenvolvimento Sustentável das Nações Unidas. Instituição Nacional - Biblioteca da Universidade (NIUL) em Bitola é confrontado com o desafio de criar as suas próprias políticas de biblioteca, comparando e utilizando os enquadramentos ou modelos existentes para as políticas de bibliotecas e informação de todo o mundo, e contribuir para o desenvolvimento com ênfase na dimensão social da desenvolvimento sustentável. O foco deste trabalho é responder à pergunta: Qual é o papel da biblioteca como uma instituição nacional em chamar para a ação e ajudar o processo de mudanças positivas para o nosso mundo.O documento irá explicar a conectividade da Universidade Biblioteca institucional Nacional (NIUL) "Sv. Kliment Ohridski "Bitola, com as cinco áreas de importância crítica para a humanidade e para o planeta: Pessoas, Planeta, Prosperidade, Paz e Parceria. Ele descreve as possibilidades de abertura de debates e tomar medidas para cumprir as metas e objetivos do Documento das Nações Unidas: "Transformar o nosso mundo: a 2030 Agenda para o Desenvolvimento Sustentável".

PALAVRAS-CHAVE: Bibliotecas nacionais. Funções de biblioteca. Metas de desenvolvimento sustentável. Macedónia. 


\section{REFERENCES}

ATD FOURTH WORLD.Challenge2015:Towards Sustainable Development that Leaves No One Behind, Executive Summary [Online]. 2014. Available at: $<$ http://www.atd-fourthworld.org/wpcontent/uploads/sites/5/2015/07/Challenge_2015_Executive_Summary.pdf $>$.Acc essed: 14th March 2016.

ATD FOURTH WORLD.Towards Sustainable Development that Leaves No One Behind The Challenge of the Post-2015 Agenda.[Online]. 2013. Available at: $<$ http://www.atd-fourthworld.org/wpcontent/uploads/old/pdf/Working_Paper_ATD_Fourth_World_Participatory_Res earch_June_2013.pdf>. Accessed 14th March 2016.

CHALLENGE 2015:Towards Sustainable Development that Leaves No One Behind, International Movement ATD Fourth World.[Online]. 2015. Available at: $<$ http://www.atd-fourthworld.org/wp-

content/uploads/old/pdf/Challenge_2015_-_ATD_Fourth_World.pdf >.Accessed: 5th May 2016.

NATIONAL PROGRAM for Development of Education in Republic of Macedonia 2005-2015. 2005. Available at: <http://fvm.ukim.edu.mk/documents/Nacionalnaprograma-za-razvoj-na-obrazovanieto-vo-Republika-Makedonija-20052015.pdf>.Accessed: 14th March 2016.

NATIONAL STRATEGY and Action Plan for Development of the Information Society.2005. [Online]. Available at:

<http://www.mio.gov.mk/files/pdf/dokumenti/Strategija_i_Akcionen_Plan.pdf>. Accessed: 14th March 2016.

NATIONAL STRATEGY to reduce Poverty and Social Exclusion in Republic of Macedonia NSPSERM (2010-2020). Revised [Online] Available at: <http://mtsp.gov.mk/WBStorage/Files/revidirana_str_siromastija.pdf>. Accessed: 14th March 2016.

NATIONAL YOUTH STRATEGY of Republic of Macedonia.[Online].2005. Available at:

<http://www.sega.org.mk/web/doc/Nacionalna\%20strategija\%20za\%20mladi\%2 Ona\%20RM.pdf>.Accessed: 14th March 2016.

NETWORK FOR INFORMATION \& Digital Access NIDA.Supporting Societies' Needs: a Model Framework for Developing Library Policy- background paper [Online]. 2011. Available at:<http://www.nidanet.org/static/files/Introduction+and+background+04.pdf>. Accessed: 26th February 2016. 
UNITED NATIONS.Resolution adopted by the General Assembly on 25

September 2015, Transforming our world: the 2030 Agenda for Sustainable Development [Online]. 2015. Available at:

<http://www.un.org/ga/search/view_doc.asp?symbol=A/RES/70/1\&Lang=E >. Accessed: 28th February 2016.

Recebido: 27 mai. 2016

Aprovado: 03 ago. 2016

DOI: $10.3895 /$ rbpd.v5n1.4581

Como citar: BOSHEVSKA, L. Sustainability is possible: The National Institution - University Library (NIUL) in Macedonia as a leader of societal development. R. bras. Planej. Desenv.,Curitiba, v. 5, n. 3, p. 419-430, set./dez. 2016. Disponível em: <https://periodicos.utfpr.edu.br/rbpd>. Acesso em: XXX.

Correspondência:

Lili Boshevska

Pece Matichevski 39, Bitola 7000, Macedônia

Direito autoral: Este artigo está licenciado sob os termos da Licença Creative Commons-Atribuição 4.0 Internacional.

\section{(c) (1)}

